\title{
Pengaruh Desain Sudu Terhadap Unjuk Kerja Prototype Turbin Angin Vertical Axis Savonius
}

\author{
Untung Surya Dharma ${ }^{1, a^{*}}$, Masherni ${ }^{2, b}$ \\ 1.Teknik Mesin, ${ }^{2}$ Teknik Sipil, Universitas Muhammadiyah Metro \\ Jl. Ki Hajar Dewantara 15 A Metro, Lampung \\ auntungsdh@yahoo.co.id \\ bMasherni21@yahoo.co.id
}

\begin{abstract}
Abstrak
Krisis energi yang terjadi berdampak pada kebutuhan energi di Indonesia khususnya dan di dunia pada umumnya terus meningkat karena pertambahan penduduk. Banyak sekali energi alternatif dari alam di Indonesia yang dimanfaatkan salah satunya sumber pembangkit listrik tenaga angin. Turbin angin ialah mesin konversi energi dengan cara memanfaatkan energi angin yang terwujud dalam energi listrik. Sudu merupakan wadah penampung suatu bentuk aliran udara yang dibuat untuk menghasilkan gaya angkat dan gaya untuk mengerakan generator. Tujuan dalam penyusunan skipsi ini adalah untuk mengetahui desain sudu terbaik dalam menciptakan daya turbin dan daya generator serta efisiensi sistem dari masing-masing sudu tersebut. Metode yang dilakukan yaitu studi literatur, dokumentasi dan pembuatan sudu serta pengujian. Turbin angin yang dibuat dengan sudu 5/16, 5/16, 7/16 variasi kecepatan angin yang diujikan $3,6 \mathrm{~m} / \mathrm{s}, 4 \mathrm{~m} / \mathrm{s}, 4,13 \mathrm{~m} / \mathrm{s}, 4,5 \mathrm{~m} / \mathrm{s}, 4,6 \mathrm{~m} / \mathrm{s}, 4,67 \mathrm{~m} / \mathrm{s}, 5,4 \mathrm{~m} / \mathrm{s}, 5,63 \mathrm{~m} / \mathrm{s}$ dan $6,1 \mathrm{~m} / \mathrm{s}$. Dari ketiga variabel sudu berdasarkan pengujian beda kecepatan angin desain terbaik yang menghasilkan daya turbin dan daya generator penelitian ini yaitu dimiliki oleh desain sudu 7/16 dengan kecepatan angin yang paling tinggi $6,1 \mathrm{~m} / \mathrm{s}$ menghasilkan daya turbinnya sebesar 6,125 Watt dan daya generatornya menghasilkan daya 4,391 Watt, sedangkan sudu 6/16 menghasilkan daya turbin 5,08 Watt dan daya generator 3,808 Watt dan sudu 5/16 hanya menghasilkan daya turbin sebesar 3,444 Watt dan daya generator sebesar 3,014 Watt. Besar efisiensi sistem masing-masing sudu hasil perhirungan dengan kecepatan angin tertinggi $6,1 \mathrm{~m} / \mathrm{s}$ yaitu sudu $5 / 16$ menghasilkan efisiensi sistemnya sebesar $18,99 \%$, nilai efisiensi sistem sudu $6 / 16$ sebesar $21,81 \%$ dan sudu $7 / 16$ menghasilkan efisiensi sistem sebesar $23,06 \%$.
\end{abstract}

\section{Kata kunci : Prototype Turbin Angin, Desain Sudu, Unjuk kerja.}

\section{Pendahuluan}

Menurut Kementerian Energi dan Sumber Daya Mineral, Direktorat Jenderal Energi Baru Terbarukan dan Konservasi Energi (EBTKE) Sumber daya energi di Indonesia dan dunia semakin menipis, dimana energi menjadi semakin langka dan semakin mahal dengan pertumbuhan konsumsi energi rata-rata $7 \%$ setahun. Sedangkan, pertumbuhan kebutuhan energi ini tidak diimbangi dengan pasokan energi yang cukup, sehingga pasokan kebutuhan energi fosil masih terlalu besar, penggunaan energi fosil sendiri dapat mengakibatkan perubahan iklim global yang disebabkan oleh meningkatnya Gas Rumah Kaca (GRK) di atmosfir bumi. Untuk memenuhi kebutuhan energi dan mengurangi GRK ini perlu ditingkatkan supaya pemanfaatan EBT (Energi Baru Terbarukan) atau energi alternatif. Salah satu energi alternatif yang mudah dan dapat digunakan adalah angin.

Potensi angin di Indonesia menurut Manajer Wind Hybrid Power Generation Project (WhyPGen) bahwa Indonesia kaya akan energi terbarukan terutama angin. Kecepatan angin dibeberapa wilayah Indonesia sekitar 2-9 meter/detik, cukup kuat untuk memutar bilah turbin 
angin. Kecepatan angin yang ada di provinsi lampung pada tahun 2014 kisaran $4 \mathrm{~m} / \mathrm{s}$ (BMKG, 2014), hal ini memungkinkan untuk membuat turbin angin sumbu vertikal dikarenakan turbin angin sumbu vertikal tersebut mampu berputar pada kecepatan angin rendah yaitu minimal $2,0 \mathrm{~m} / \mathrm{s}$.

Daya turbin pada turbin angin sangat tergantung oleh kecepatan angin dan desain sudu ialah bentuk sayap dari sebuah turbin angin untuk menampung dari sebuah aliran udara yang mendorong sudu turbin yang dapat menghasilkan gaya angkat atau gaya dorong. Airfoil merupakan bentuk dari potongan melintang sudu yang dihasilkan oleh perpotongan tegak lurus sudu terhadap rotor. Dengan demikian daya yang dihasilkan oleh turbin dapat disimpulkan tergantung dari desain sudu. Banyak penelitian menguraikan tentang gaya dorong yang dihasilkan oleh airfoil yang dimanfaatkan guna memperbesar torsi yang dihasilkan.

Penelitian terdahulu yang telah dilakukan oleh penulis [1], tentang Analisa Unjuk Kerja Turbin Angin Vertical Axis Savonius Untuk Pembangkit Listrik Skala Rumah Tangga Di Kota Metro, diketahui daya yang dihasilkan hanya sebesar 1, 4 watt.

Dari pemaparan diatas, penelitian lanjutan ini diharapkan dapat menjelaskan bagaimana unjuk kerja dari Prototype Turbin Angin yang telah dibuat apabila menggunakan variasi ukuran sudu pada kecepatan angin rendah, guna mendapatkan daya dan efisiensi sistem yang lebih baik.

\section{Tinjauan Teoritis}

Menurut penelitian Ikhwanul Ikhsan \& Muhammad Akbar Hipi pada tahun 2011 [2], yang membahas mengenai pengaruh pembebanan terhadap kinerja kincir dengan variasi kecepatan angin 3 $\mathrm{m} / \mathrm{s}$ menghasilkan daya maksimum 0,8933 Watt dan torsi maksimum 0,0461 $\mathrm{Nm}$. Pada kecepatan angin $4 \mathrm{~m} / \mathrm{s}$ daya maksimumnya 1,4786 Watt dengan torsi maksimumnya mencapai $0,0638 \mathrm{Nm}$ dan pada kecepatan angin $5 \mathrm{~m} / \mathrm{s}$ menghasilkan daya maksimum sebesar 2,5156 Watt dan torsi maksimum $0,0883 \mathrm{Nm}$, sedangkan pada kecepatan angin $6 \mathrm{~m} / \mathrm{s}$ daya maksimum yang dihasilkan sebesar 3,9428 Watt dan torsi maksimum 0,1158 $\mathrm{Nm}$.

Sedangkan menurut penelitian Andri Kusbiantoro dkk, pada tahun 2009, [3] yang membahas mengenai pengaruh panjang lengkung sudu terhadap unjuk kerja turbin angin poros vertikal savonius, dengan panjang lengkung sudu 5/12 dan $6 / 12$. Menghasilkan 0,043 Watt dengan kecepatan angin $3 \mathrm{~m} / \mathrm{s}$ pada lengkung sudu 5/12. Pada panjang lengkung sudu 6/12 dengan kecepatan angin $7 \mathrm{~m} / \mathrm{s}$ menghasilkan 0,441 watt. Serta efisiensi tertingginya adalah $10,16 \%$. Pada penelitian menunjukkan bahwa bentuk sudu sangat berkaitan erat dengan daya yang dihasilkan sudu tersebut.

Dari penelitian dari Muhammad Fariedl Faqihuddin and Friend pada tahun 2014, [4] yang mengupas mengenai karakteristik model turbin angin dengan menggunakan suatu bentuk sudu yang konstan, dengan karakteristik sebagai berikut, diameter sudu $70 \mathrm{~cm}$, sudut pitch $10^{\circ}$, pada kecepatan angin $2-3,23 \mathrm{~m} / \mathrm{s}$ menghasilkan daya 0,605 Watt pada putaran $406 \mathrm{rpm}$ pada $c p 0,18$ pada tip speed ratio sebesar 6,1 , daya 1,311 Watt pada putaran $513 \mathrm{rpm}, c p 0,21$ dengan pada tip speed ratio sebesar 6,3 dan daya 1,673 Watt pada putaran $561 \mathrm{rpm}, c p 0,21$ tip speed ratio 6,3 . Hal ini membuktikan bahwa pengaruh dari bentuk dengan spesifikasi tertentu oleh sebuah sudu, dapat memvariasikan daya yang dihasilkan.

\section{Turbin Angin Sumbu Vertikal}

Turbin angin sumbu vertikal atau tegak (TASV) memiliki poros atau sumbu rotor utama yang disusun tegak lurus dengan sudu turbin. Kelebihan utama susunan ini adalah turbin tidak harus 
diarahkan ke angin agar menjadi efektif. Kelebihan ini sangat berguna di tempattempat yang arah anginnya sangat bervariasi. VAWT mampu mendayagunakan angin dari berbagai arah. Dengan sumbu yang vertikal, generator serta gearbox bisa ditempatkan di dekat tanah, jadi menara tidak perlu menyokongnya dan lebih mudah diakses untuk keperluan perawatan. Tapi ini menyebabkan sejumlah desain menghasilkan tenaga putaran yang berdenyut. Drag gaya yang menahan pergerakan sebuah benda padat melalui fluida (zat cair atau gas) bisa saja tercipta saat kincir berputar.

Ada beberapa kelebihan yang dimiliki oleh kincir sumbu vertikal, antara lain : aman, mudah membangunnya, bisa dipasang tidak jauh dari tanah, dan lebih baik dalam menangani turbulensi angin. Generator dan gearbox bisa ditempatkan tidak jauh dari permukaan tanah. Hal ini meringankan beban tower dan memudahkan perawatan. Kincir sumbu vertikal yang lazim digunakan adalah Savonius dan Darrieus.

\section{Savonius}

Savonius merupakan jenis kincir angin yang paling sederhana dan versi besar dari anemometer. Kincir Savonius dapat berputar karena adanya gaya tarik (drag). Efisiensi yang bisa dicapai turbin angin jenis ini sekitar $30 \%$.

\section{Darrieus}

Kincir angin Darrieus mempunyai bilah sudu yang disusun dalam posisi simetri dengan sudut bilah diatur relatif terhadap poros. Pengaturan ini cukup efektif untuk menangkap berbagai arah angin. Berbeda dengan Savonius, Darrieus memanfaatkan gaya angkat yang terjadi ketika angin bertiup. Bilah sudu turbin Darrieus bergerak berputar mengelilingi sumbu.

\section{Sudu (Blade)}

Sudu merupakan suatu penampang yang menampung bentuk aliran udara yang dibuat untuk menghasilkan gaya angkat dan gaya dorong pada saat tertentu yang dimanfaatkan oleh turbin angin. Gaya dorong yang dihasilkan oleh sudu inilah yang kemudian dimanfaatkan menghasilkan torsi. Besar kecilnya gaya angkat yang terjadi akan berubah-ubah tergantung desain sudu dan kondisi operasinya. Pada pesawat terbang, gaya angkat pada sayap utama digunakan sebagai gaya pelawan, gaya berat pesawat yang memungkinkan pesawat terbang dapat lepas landas dan tetap melayang di angkasa, selain itu gaya angkat pada sayap-sayap pembeloknya digunakan untuk manuver pesawat ketika berada di udara dengan cara mengubah ubah sudut serangnya sehingga gaya angkat yang dihasilkan dapat diatur sedemikian rupa untuk menghasilkan gerakan yang diinginkan; vertikal, horisontal, ataupun memutar terhadap sumbu aksial Gaya dorong yang dihasilkan pada sudu-sudu turbin angin dimanfaatkan untuk memutar generator listrik yang terhubung dengan poros turbin angin. Agar generator listrik dapat bekerja dengan baik dan aman maka putaran harus selalu dijaga pada kisaran tertentu.

$\begin{array}{cccc}\text { Sudu } & \text { dapat menghasilkan gaya } \\ \text { dorong } & \text { yang } & \text { dibutuhkan untuk }\end{array}$ mempertahankan turbin angin supaya tetap berputar. Untuk menghasilkan gaya dorong ini maka sudu tersebut perlu terus bberputar. Bentuk dari suatu sayap atau sudu - sudu yang dapat menghasilkan gaya dorong ketika ditumbok oleh suatu bentuk aliran udara (Airfoil). Rotor kincir angin terdiri dari satu atau lebih sudu sudu yang melekat pada poros turbin (pusat dari sudu ).

Gaya dorong yaitu gaya yang dialami oleh objek didalam aliran udara yang searah dengan aliran udara, sedangkan gaya angkat merupakan gaya yang dialami objek dalam aliran udara yang tegak lurus arah aliran udara tersebut. Sudut yang dibentuk oleh objek terdapat arah aliran yang diukur terhadap suatu garis referensi pada objek disebut 
angle of attack $(\alpha)$, garis referensi pada penampang airfoil biasa disebut chord line. Airfoil merupakan penampang objek yang dirancang untuk meminimalisasi gaya dorong. Bentuknya bulat pada bagian hidung (leading edge) dan lancip pada bagian ekornya (trailing edge). Hal ini dapat ditunjukan pada gambar berikut [5] :

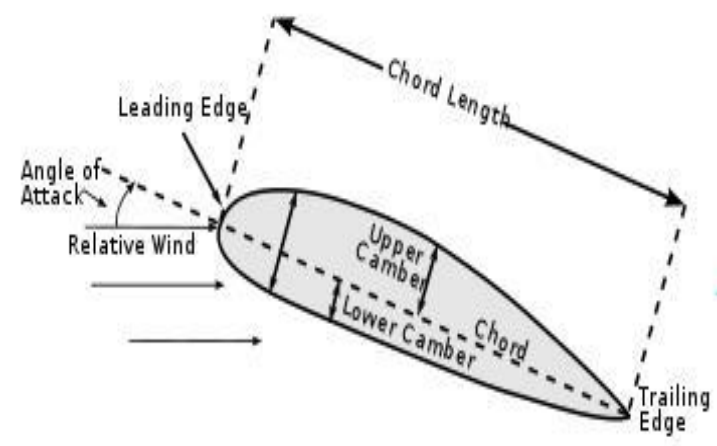

Gambar 1. Bagian penampang airfoil

Setiap permukaan airfoil yang mengalir udara terdapat dua gaya yang bekerja yaitu gaya hambat dan gaya angkat. Gaya hambat adalah gaya yang diukur sejajar dengan aliran udara yang menabrak kincir, gaya ini umumnya diperkecil dalam perancangan kincir. Gaya angkat merupakan gaya yang diukur tegak lurus dari aliran udara yang menabrak kincir.

Besarnya gaya dorong dan gaya angkat tergantung oleh sudut serang $(\alpha)$. Dalam perancangan airfoil yang terpenting adalah rasio koefisien gaya dorong dan koefisien gaya angkat harus diminimalisasikan agar didapat efek aerodinamika yang seefisien mungkin.

\section{Parameter - Parameter Analisa}

\section{a. Menentukan Luas Plat Yang} Digunakan Sebagai Bahan Sudu

Dalam menentukan luas plat yang akan digunakan untuk membuat sudu dapat diketahui dengan mencari sudut $(\alpha)$ atau sudut yang dibentuk oleh kedua ujung plat setelah proses pembentukan sudu. Adapun persamaan untuk menentukan sudut $(\alpha)$ yaitu sebagai berikut ini [6]:

Dimana :

$$
\begin{aligned}
& h=\frac{L}{2} \cdot \tan \frac{\alpha}{4} \\
& \text { maka, } \\
& \frac{2 h}{L}=\tan \frac{\alpha}{4}
\end{aligned}
$$

$\mathrm{h}=$ tinggi lengkungan sudu $(\mathrm{m})$

$\mathrm{L}=$ lebar sudu $(\mathrm{m})$

Setelah diketahui sudut ( $\alpha)$, maka untuk menentukan jari-jari sudu dapat digunakan persamaan berikut :

$$
\begin{aligned}
& L=2 \cdot r \cdot \sin \frac{\alpha}{2} \\
& \text { Maka, } \\
& \quad r=\frac{L}{2 \cdot \sin \frac{\alpha}{2}}
\end{aligned}
$$

Dimana :

$$
\begin{aligned}
& L=\operatorname{Lebar} \operatorname{sudu}(m) \\
& r=\operatorname{Jari}-\text { jari sudu }(m)
\end{aligned}
$$

Setelah Jari - jari sudah diketahui maka untuk menentukan lebar plat yang akan digunakan dapat diperoleh dengan persamaan:

$b=\frac{\pi \cdot d \cdot \alpha}{360}$

Dimana :

$$
\begin{aligned}
\mathrm{b}= & \text { lebar } \quad \text { sudu } \\
& \text { dilengkungkan }(\mathrm{m}) \\
\mathrm{d}= & \text { Diameter sudu }(\mathrm{m})
\end{aligned}
$$

Maka luas plat yang akan digunakan sebagai bahan sudu dapat diketahui dengan persamaan berikut :

$$
A=t . b
$$

Dimana :

$\begin{aligned} \mathrm{A}= & \text { Luas penampang sudu setelah } \\ & \text { dilengkungkan }=\text { luas } \\ & \text { penampang sapuan }\left(\mathrm{m}^{2}\right) \\ \mathrm{t}= & \text { panjang sudu }(\mathrm{m}) \\ \mathrm{b}= & \text { lebar setelah dilengkungkan } \\ & (\mathrm{m})\end{aligned}$




\section{b. Daya Angin}

Daya yang dimiliki oleh angin untuk memutarkan sudu dapat diperoleh dari persamaan berikut [7]: $P_{A}=\frac{1}{2} \cdot \rho \cdot A \cdot v^{3}$

Dimana :

$$
\begin{aligned}
& \left.P_{A}=\text { Daya angin (Watt }\right) \\
& \rho=\text { Massa jenis udara }\left(\mathrm{kg} / \mathrm{m}^{3}\right) \\
& A=\text { Luas penampang sapuan }\left(\mathrm{m}^{2}\right) \\
& v=\text { Kecepatan angin }(\mathrm{m} / \mathrm{s})
\end{aligned}
$$

\section{c. Daya Turbin}

Daya turbin merupakan output dari daya angin, daya turbin dapat diperoleh dengan persamaan berikut :

$$
P_{T}=\omega \cdot T
$$

Dimana :

$$
\begin{aligned}
P_{T} & =\text { Daya turbin }(\text { Watt }) \\
T & =\text { Torsi }(\text { N.m }) \\
\omega & =\text { Kecepatan sudut }(\mathrm{rad} / \mathrm{s})
\end{aligned}
$$

\section{d. Daya Generator}

Daya genetator turbin dapat diperoleh dengan persamaan berikut [8] :

$$
P_{g}=V . I
$$

Dimana :

$$
\begin{aligned}
P_{g} & =\text { Daya generator }(\text { Watt }) \\
V & =\text { Tegangan listrik }(\text { volt }) \\
I & =\text { Kuat arus listrik }(\text { amper })
\end{aligned}
$$

\section{e. Efisiensi Sistem}

Efisiensi sistem merupakan perbandingan antara daya generator angin dan daya angin dari turbin angin, dapat ditulis dengan persamaan [9]

$$
\eta=\frac{P_{g}}{P_{A}} .100 \%
$$

Dimana :

$$
\begin{array}{ll}
\eta & =\text { Efisien sisistem }(\%) \\
P_{g} & =\text { Daya generator }(\text { Watt }) \\
P_{A} & =\text { Daya angin }(\text { Watt })
\end{array}
$$

\section{Metode Penelitian}

\section{Tempat penelitian}

Penelitian dilakukan dari bulan Februari sampai dengan November 2016. Adapun tempat pembuatan dan pengujian prototype turbin angin savonius dilakukan di Laboratorium Terpadu Jurusan Teknik Mesin Fakultas Teknik Universitas Muhammadiyah Metro.

\section{Alat dan Bahan Penelitian}
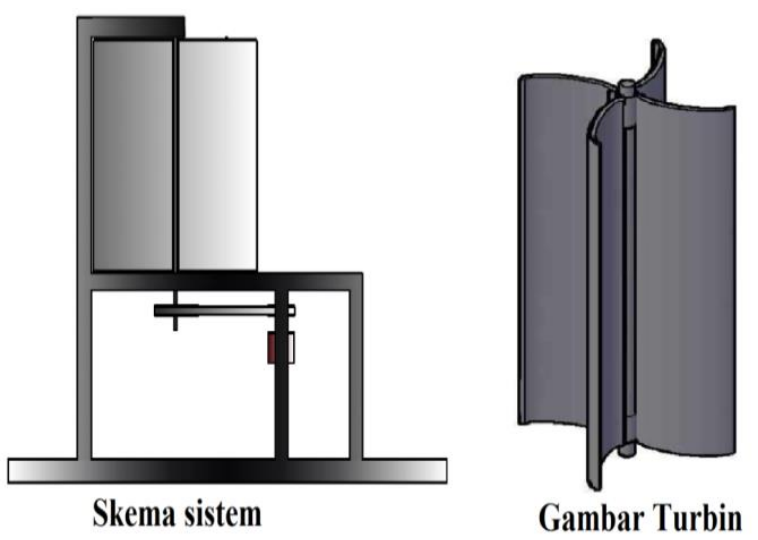

Skema sistem

Gambar 2. Konsep Rancangan VAWT [1]
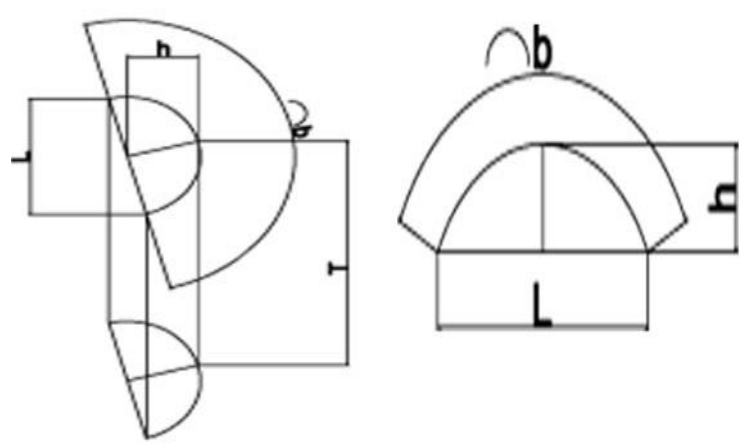

\footnotetext{
Keterangan gambar :

a. h adalah tinggi lengkungan sudu

b. $t$ adalah panjang sudu

c. L adalah lebar sudu
}

Gambar 3. Bentuk dan Ukuran Sudu

\section{Prosedur pengujian}

Adapun prosedur pengujian untuk pengambilan data lapangan adalah sebagai berikut : 
1. Buatlah 3 variasi sudu dengan bentuk dan ukuran sebagai berikut :

a. Sudu dengan ratio $\mathrm{h} / \mathrm{L}=5 / 16$ dengan luas plat $0,12 \mathrm{~m}^{2}$.

b. Sudu dengan ratio $h / L=6 / 16$ dengan luas plat $0,132 \mathrm{~m}^{2}$

c. Sudu dengan ratio $\mathrm{h} / \mathrm{L}=7 / 16$ dengan luas plat $0,144 \mathrm{~m}^{2}$

2. Posisikan turbin angin di lapangan yang telah ditentukan dengan menggunakan salah satu variasi sudu.

3. Ambil data putaran poros turbin yang terjadi dengan menggunakan tachometer

4. Ambil data gaya pembebanan yang terjadi pada turbin dengan cara menggunakan tali yang salah satu ujungnya diikat dengan neraca pegas, dan ujung yang lainnya diikat pada puli transmisi. Sehingga ketika turbin berputar, puli akan menarik tali yang berhubungan langsung pada neraca pegas. Nilai gaya pembebanan akan terlihat, data tersebut dikalikan dengan jari - jari puli untuk menghitung torsi yang terjadi.

5. Ambil data tegangan (voltase) dan kuat arus listrik (ampere) yang dihasilkan menggunakan multimetertester.

6. Dari data-data diatas hitung nilai torsi, daya poros, daya listik dan efisensi sistem untuk mengetahui unjuk kerja yang mampu dihasilkan oleh turbin angin sebenarnya.

7. Ulangi seluruh langkah-langkah pengambilan data untuk setiap variasi sudu.

\section{Hasil Dan Pembahasan}

\section{A. Data Hasil Pengujian}

Adapun data hasil pengujian yan telah dilakukan pada prototye turbin angin dengan variasi ukuran blade seperti dalam Tabel 1.
Tabel 1. Hasil pengujian Prototype Turbin dengan Variasi Ukuran Blade

\begin{tabular}{|c|c|c|c|c|c|c|c|c|c|c|}
\hline \multirow{2}{*}{$\begin{array}{c}\text { Kecepatan } \\
\text { Angin }\end{array}$} & \multirow{2}{*}{$\begin{array}{c}\text { Variasi } \\
\text { sudu }\end{array}$} & \multicolumn{2}{|c|}{$\begin{array}{c}\text { Pembebanan } \\
(\mathrm{Kg})\end{array}$} & \multicolumn{5}{|c|}{ Putaran (rpm) } & \multicolumn{2}{|c|}{$\begin{array}{c}\text { Out } \\
\text { Generator }\end{array}$} \\
\hline & & $P b_{1}$ & $P b_{2} 2$ & $n_{1}$ & $n_{2}$ & $n_{3}$ & $n_{4}$ & $n_{5}$ & $\mathrm{~V}$ & A \\
\hline \multirow{3}{*}{$3,6 \mathrm{~m} / \mathrm{s}$} & $5 / 16$ & 2,4 & \begin{tabular}{|l|}
1,067 \\
\end{tabular} & \begin{tabular}{|l|}
47,87 \\
\end{tabular} & 23,73 & 43,83 & \begin{tabular}{|l|}
6,767 \\
\end{tabular} & \begin{tabular}{|l|}
15,67 \\
\end{tabular} & 4,387 & 0,1 \\
\hline & $6 / 16$ & 4,06 & \begin{tabular}{|l|}
1,383 \\
\end{tabular} & 48,23 & 28,83 & 54,2 & \begin{tabular}{|l|}
18,4 \\
\end{tabular} & \begin{tabular}{|l|}
37,77 \\
\end{tabular} & 4,927 & 0,101 \\
\hline & $7 / 16$ & 4,383 & \begin{tabular}{|l|}
1,433 \\
\end{tabular} & \begin{tabular}{|l|}
88,53 \\
\end{tabular} & 34,03 & 55,4 & 28,27 & \begin{tabular}{|l|}
47,83 \\
\end{tabular} & 5,827 & 0,103 \\
\hline & & & & & & & & & & \\
\hline \multirow{3}{*}{$4 \mathrm{~m} / \mathrm{s}$} & $5 / 16$ & 3,5 & \begin{tabular}{|l|}
1,25 \\
\end{tabular} & 63,5 & 32,63 & \begin{tabular}{|l|}
46,53 \\
\end{tabular} & 15,9 & \begin{tabular}{|l|}
35,83 \\
\end{tabular} & \begin{tabular}{|l|}
6,167 \\
\end{tabular} & 0,1 \\
\hline & $6 / 16$ & 4,25 & 1,483 & 84,4 & \begin{tabular}{|l|}
38,57 \\
\end{tabular} & 54,2 & \begin{tabular}{|l|}
19,77 \\
\end{tabular} & \begin{tabular}{|l|}
48,77 \\
\end{tabular} & 7,455 & 0,105 \\
\hline & $7 / 16$ & 4,467 & 2,333 & 91,73 & 39,13 & 59,33 & 33,57 & 59,5 & 8,547 & 0,106 \\
\hline \multirow{3}{*}{$4,13 \mathrm{~m} / \mathrm{s}$} & $5 / 16$ & 3,5 & \begin{tabular}{|l|}
1,367 \\
\end{tabular} & 85,8 & \begin{tabular}{|l|}
41,17 \\
\end{tabular} & \begin{tabular}{|l|}
53,57 \\
\end{tabular} & \begin{tabular}{|l|}
21,73 \\
\end{tabular} & 52,43 & \begin{tabular}{|l|}
6,41 \\
\end{tabular} & 0,109 \\
\hline & $6 / 16$ & \begin{tabular}{|l|l|}
4,637 \\
\end{tabular} & 1,5 & \begin{tabular}{|l|}
89,97 \\
\end{tabular} & 42,8 & 56,23 & \begin{tabular}{|l|}
32,97 \\
\end{tabular} & \begin{tabular}{|l|}
55,7 \\
\end{tabular} & 7,747 & 0,111 \\
\hline & $7 / 16$ & 5,367 & \begin{tabular}{|l|}
2,35 \\
\end{tabular} & \begin{tabular}{|l|}
100,1 \\
\end{tabular} & 50,3 & 97,73 & 36,93 & \begin{tabular}{|l|}
67,57 \\
\end{tabular} & 9,08 & 0,112 \\
\hline \multirow{4}{*}{$4,5 \mathrm{~m} / \mathrm{s}$} & & & & & & & & & & \\
\hline & $5 / 16$ & 3,533 & \begin{tabular}{|l|}
2,067 \\
\end{tabular} & \begin{tabular}{|l|}
87,37 \\
\end{tabular} & 43,03 & 65,03 & 26,53 & 59,3 & \begin{tabular}{|l|}
8,36 \\
\end{tabular} & 0,111 \\
\hline & $6 / 16$ & 5,233 & \begin{tabular}{|l|}
2,35 \\
\end{tabular} & \begin{tabular}{|l|}
92,07 \\
\end{tabular} & 46,2 & 94,37 & 40,2 & \begin{tabular}{|l|}
65,6 \\
\end{tabular} & 10,32 & 0,112 \\
\hline & $7 / 16$ & 5,417 & 2,717 & \begin{tabular}{|l|}
106,4 \\
\end{tabular} & 51,77 & 100,5 & 41,9 & 75,67 & 11,87 & 0,112 \\
\hline \multirow{3}{*}{$4,6 \mathrm{~m} / \mathrm{s}$} & $5 / 16$ & 45 & 22 & 9207 & 478 & 8763 & 29,43 & 7067 & 979 & 0112 \\
\hline & $6 / 16$ & 5,4 & \begin{tabular}{|l|}
2,583 \\
\end{tabular} & \begin{tabular}{|l|}
106,9 \\
\end{tabular} & \begin{tabular}{|l|}
52,77 \\
\end{tabular} & 97,27 & \begin{tabular}{|l|}
41,73 \\
\end{tabular} & \begin{tabular}{|l|}
79,37 \\
\end{tabular} & 11,42 & 0,117 \\
\hline & $7 / 16$ & 5,5 & 3,207 & 112,5 & \begin{tabular}{|l|}
54,4 \\
\end{tabular} & 106,5 & 43,7 & 81,43 & 13,45 & 0,118 \\
\hline \multirow{3}{*}{$4,67 \mathrm{~m} / \mathrm{s}$} & $5 / 16$ & \begin{tabular}{|l|l|}
4,667 \\
\end{tabular} & 2,5 & \begin{tabular}{|l|}
92,97 \\
\end{tabular} & \begin{tabular}{|l|}
58,57 \\
\end{tabular} & 87,67 & \begin{tabular}{|l|}
35,67 \\
\end{tabular} & \begin{tabular}{|l|}
77,37 \\
\end{tabular} & \begin{tabular}{|l|}
10,03 \\
\end{tabular} & 0,115 \\
\hline & $6 / 16$ & \begin{tabular}{|l|l|}
5,917 \\
\end{tabular} & \begin{tabular}{|l|}
3,133 \\
\end{tabular} & \begin{tabular}{|l|}
114,1 \\
\end{tabular} & \begin{tabular}{|l|}
63,17 \\
\end{tabular} & 99,97 & \begin{tabular}{|l|}
42,57 \\
\end{tabular} & \begin{tabular}{|l|}
96,1 \\
\end{tabular} & 11,93 & 0,123 \\
\hline & $7 / 16$ & 6 & 3,4 & \begin{tabular}{|l|}
120,8 \\
\end{tabular} & \begin{tabular}{|l|}
65,8 \\
\end{tabular} & 117,4 & \begin{tabular}{|l|}
43,7 \\
\end{tabular} & \begin{tabular}{|l|}
100,3 \\
\end{tabular} & 13,59 & 0,125 \\
\hline & & & & & & & & & & \\
\hline \multirow{3}{*}{$5,4 \mathrm{~m} / \mathrm{s}$} & $5 / 16$ & \begin{tabular}{|l|l|}
4,933 \\
\end{tabular} & \begin{tabular}{|l|}
3,067 \\
\end{tabular} & \begin{tabular}{|l|}
98,27 \\
\end{tabular} & \begin{tabular}{|l|}
60,47 \\
\end{tabular} & 110,3 & \begin{tabular}{|l|}
41,87 \\
\end{tabular} & \begin{tabular}{|l|}
79,97 \\
\end{tabular} & 16,66 & 0,118 \\
\hline & $6 / 16$ & 5,933 & 3,14 & \begin{tabular}{|l|}
115,5 \\
\end{tabular} & 64,3 & 117,8 & 43,97 & \begin{tabular}{|l|}
97,17 \\
\end{tabular} & 18,95 & 0,125 \\
\hline & $7 / 16$ & 6,167 & 3,4 & 125 & 66,7 & 120,3 & 49,93 & \begin{tabular}{|l|}
100,7 \\
\end{tabular} & 22,63 & 0,126 \\
\hline & 5116 & 5137 & 31 & 1008 & 676 & 1105 & 424 & 9667 & 1877 & 0123 \\
\hline \multirow{2}{*}{$5,63 \mathrm{~m} / \mathrm{s}$} & $\begin{array}{l}3 / 10 \\
6 / 16\end{array}$ & \begin{tabular}{|l|l|}
5,131 \\
6,083
\end{tabular} & $\frac{3,1}{3,25}$ & \begin{tabular}{|l|}
100,8 \\
122,3 \\
\end{tabular} & \begin{tabular}{|c|}
$0 /, 0$ \\
71,67 \\
\end{tabular} & 118,2 & \begin{tabular}{|l|}
42,4 \\
44,93 \\
\end{tabular} & \begin{tabular}{|l|}
102,37 \\
\end{tabular} & $\frac{10,71}{21,61}$ & \begin{tabular}{|l|l|}
0,125 \\
\end{tabular} \\
\hline & $7 / 16$ & \begin{tabular}{|l|}
6,35 \\
\end{tabular} & 3.8 & 125,4 & 76,43 & 122,4 & \begin{tabular}{|l|}
55,57 \\
\end{tabular} & \begin{tabular}{|l|}
104,9 \\
\end{tabular} & 25,4 & 0,13 \\
\hline \multirow{3}{*}{$6,1 \mathrm{~m} / \mathrm{s}$} & $5 / 16$ & 6 & \begin{tabular}{|l|}
3,117 \\
\end{tabular} & 111,9 & \begin{tabular}{|l|}
98,27 \\
\end{tabular} & 124,9 & 43,93 & \begin{tabular}{|l|}
104,4 \\
\end{tabular} & 23,55 & 0,128 \\
\hline & $6 / 16$ & 7,75 & 3,3 & \begin{tabular}{|l|}
127,7 \\
\end{tabular} & \begin{tabular}{|l|}
114,1 \\
\end{tabular} & 126,6 & 62,17 & \begin{tabular}{|l|}
104,7 \\
\end{tabular} & 29,07 & 0,131 \\
\hline & $7 / 16$ & 9,25 & \begin{tabular}{|l|}
4,383 \\
\end{tabular} & \begin{tabular}{|l|}
129,2 \\
\end{tabular} & \begin{tabular}{|l|}
120,8 \\
\end{tabular} & 131,7 & \begin{tabular}{|l|}
70,63 \\
\end{tabular} & \begin{tabular}{|l|}
105,2 \\
\end{tabular} & 33,02 & 0,133 \\
\hline
\end{tabular}

\section{B. Hasil Perhitungan}

Tabel 2. Hasil Perhitungan Data Pengujian Prototype Turbin Angin dg Variasi Sudu

\begin{tabular}{|c|c|c|c|c|c|c|c|c|c|}
\hline \multirow{2}{*}{$\begin{array}{c}\text { Kecepatan } \\
\text { Angin } \\
\text { (m/s) }\end{array}$} & \multicolumn{2}{|c|}{ Daya Turbin (Watt) } & \multicolumn{2}{|c|}{ Daya Generator (Watt) } & \multicolumn{3}{|c|}{ Efisiensi sistem (\%) } \\
\cline { 2 - 10 } & $5 / 16$ & 61116 & $7 / 16$ & $5 / 16$ & $6 / 16$ & $7 / 16$ & $5 / 16$ & $6 / 16$ & $7 / 16$ \\
\hline 3,6 & 0,586 & 1,004 & 1,983 & 0,438 & 0,516 & 0,617 & 9,02 & 10,63 & 12,71 \\
\hline 4 & 1,149 & 1,958 & 2,294 & 0,641 & 0,752 & 0,88 & 9,63 & 11,29 & 13,27 \\
\hline 4,13 & 1,535 & 2,187 & 2,777 & 0,703 & 0,906 & 1,071 & 9,59 & 12,36 & 14,61 \\
\hline 4,5 & 1,563 & 2,261 & 2,784 & 1,003 & 1,267 & 1,495 & 10,58 & 13,41 & 15,77 \\
\hline 4,6 & 2,218 & 2,953 & 3,167 & 1,063 & 1,29 & 1,506 & 10,5 & 12,74 & 14,87 \\
\hline 4,67 & 2,262 & 3,506 & 3,818 & 1,113 & 1,336 & 1,522 & 10,5 & 12,61 & 14,36 \\
\hline 5,4 & 2,322 & 3,559 & 3,847 & 1,965 & 2,33 & 2,832 & 11,99 & 14,22 & 17,29 \\
\hline 5,63 & 2,684 & 3,725 & 4,081 & 2,142 & 2,576 & 2,896 & 11,54 & 13,88 & 15,32 \\
\hline 6,1 & 3,444 & 5,08 & 6,125 & 3,014 & 3,808 & 4,391 & 12,76 & 16,13 & 18,66 \\
\hline
\end{tabular}

\section{Pembahasan}

\section{Daya Turbin Angin yang dihasilkan dengan Variasi Ukuran Blade}

Dari grafik pada Gambar 4 dapat kita ketahui bahwa kecepatan angin berpengaruh terhadap daya turbin yang dihasilkan. Pada awal sampai akhir grafik hubungan antara 
kecepatan angin terhadap daya turbin pada sudu yang sama mengalami kecenderungan yang meningkat terlihat pada grafik bahwa pada kecepatan angin 3,6 daya terbesar diperoleh dengan nilai 1,983 Watt yaitu pada sudu 7/16, sedangkan sudu 6/16 menghasilkan nilai daya turbin sebesar 1,004 Watt nilai tersebut lebih kecil dibanding dengan sudu 7/16. Sedangkan sudu 5/16 pada kecepatan angin $3,6 \mathrm{~m} / \mathrm{s}$ menghasilkan daya turbin sebesar 0,586 Watt.

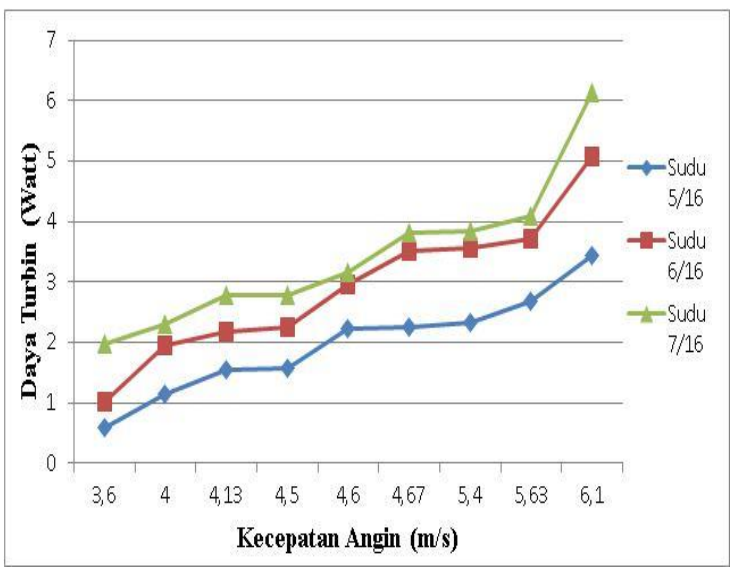

Gambar 4. Grafik daya turbin yang dihasilkan berdasarkan variasi sudu

Sedangkan dalam pengujian berdasarkan kecepatan angin $4 \mathrm{~m} / \mathrm{s}$ nilai yang dihasilkan oleh sudu 7/16 daya turbin yang dihasilkan 2,294 Watt dan untuk sudu 6/16 daya yang dihasilkan pada pengujian kecepatan angin 4 $\mathrm{m} / \mathrm{s}$ nilai daya turbinnya sebesar 1,958 Watt, nila terkecil dalam pengujian dengan kecepatan angin $4 \mathrm{~m} / \mathrm{s}$ yaitu pada sudu $5 / 16$ daya yang dihasilkan sebesar 1,149 Watt.

Nilai daya turbin terbesar yang dihasilkan oleh pengujian dengan kecepatan angin $4,13 \mathrm{~m} / \mathrm{s}$ didapatkan daya turbin terbesar oleh sudu 7/16 dengan nilai dayanya 2,777 Watt, sedangkan sudu 6/16 menghasilkan daya 2,187 Watt pada pengujian dengan kecepatan $4,13 \mathrm{~m} / \mathrm{s}$, sedang nilai terkecil dihasilkan sudu 5/16 dengan daya turbin yang dihasilkan 1,535 Watt pada kecepatan $4,13 \mathrm{~m} / \mathrm{s}$.

Dalam pengujian dengan kecepatan angin $4,5 \mathrm{~m} / \mathrm{s}$ daya turbin terbesar di hasilkan oleh sudu 7/16 dengan nilai dayanya sebesar 2,784 Watt, sedangkan sudu 6/16 hanya menghasilkan daya sebasar 2,261 Watt yang dilakukan dalam pengujian dengan kecepatan angin $4,5 \mathrm{~m} / \mathrm{s}$, nilai terkecil dalam pengujian dengan kecepatan angin 4,5 $\mathrm{m} / \mathrm{s}$ menghasilkan daya turbin 1,563 Watt oleh sudu 5/16.

Nilai daya turbin dalam pengujian dengan kecepatan angin 4,6 m/s sudu 7/16 daya turbin yang dihasilkan sebasar 3,167 Waatt, sedangkan sudu 6/16 menghasilkan daya turbin 2,953 Watt pada kecepatan angin $4,6 \mathrm{~m} / \mathrm{s}$ dan nilai yang terkecil dihasilkan oleh sudu 5/16 dengan daya turbinnya 2,218 Watt pada kecepatan $4,6 \mathrm{~m} / \mathrm{s}$.

Pengujian kecepatan angin $4,67 \mathrm{~m} / \mathrm{s}$ terhadap hasil daya turbin oleh sudu 7/16 menghasilkan daya turbin sebesar 3,818 Watt sedangka sudu $6 / 16$ menghasilkan daya turbin 3,506 Watt dan pada pengujian dengan kecepatan angin 4,67 m/s sudu 5/16 menghasilkan daya turbin sebesar 2,262 Watt.

Berdasarkan hasil pengujian kecepatan angin $5,4 \mathrm{~m} / \mathrm{s}$ nilai yang dihasilkan oleh sudu $7 / 16$ daya turbin yang dihasilkan 3,847 Watt dan untuk sudu $6 / 16$ daya yang dihasilkan pada pengujian kecepatan angin $5,4 \mathrm{~m} / \mathrm{s}$ nilai daya turbinnya sebesar 3,559 Watt, nila terkecil dalam pengujian dengan kecepatan angin $5,4 \mathrm{~m} / \mathrm{s}$ yaitu pada sudu $5 / 16$ daya yang dihasilkan sebesar 2,322 Watt.

Nilai daya turbin terbesar yang dihasilkan oleh pengujian dengan kecepatan angin $5,63 \mathrm{~m} / \mathrm{s}$ pada grafik didapatkan daya turbin terbesar oleh sudu 7/16 dengan nilai dayanya 4,081 Watt, sedangkan sudu 6/16 menghasilkan daya 3,725 Watt pada pengujian dengan kecepatan $5,63 \mathrm{~m} / \mathrm{s}$, sedang nilai terkecil dihasilkan sudu 5/16 dengan daya turbin yang dihasilkan 2,684 Watt pada kecepatan $5,63 \mathrm{~m} / \mathrm{s}$.

Sedangkan dalam pengujian berdasarkan kecepatan angin $6,1 \mathrm{~m} / \mathrm{s}$ nilai yang dihasilkan oleh sudu 7/16 daya turbin yang dihasilkan 6,125 Watt dan untuk sudu 6/16 daya yang dihasilkan pada pengujian kecepatan angin $6,1 \mathrm{~m} / \mathrm{s}$ nilai daya turbinnya sebesar 5,08 Watt, nila terkecil dalam pengujian dengan kecepatan angin $6,1 \mathrm{~m} / \mathrm{s}$ yaitu pada sudu $5 / 16$ daya yang dihasilkan sebesar 3,444 Watt.

\section{Daya Generator yang dihasilkan dengan Variasi Ukuran Blade}

Dari grafik pada Gambar 5, perbandingan daya generator yang dihasilkan berdasarkan kecepatan angin menunjukan bahwa kecepatan angin sangat mempengaruhi hasi daya generator dimana dari awal hingga akhir pengujian mengalami peningkatan dima 
na pada kecepatan angin $3,6 \mathrm{~m} / \mathrm{s}$ nilai terbesar dari menghasilkan daya generator didapatkan oleh sudu 7/16 dengan daya generator sebesar 0,617 Watt, sedangkan sudu 6/16 pada pengujian menggunakan kecepatan angin 3,6 $\mathrm{m} / \mathrm{s}$ menghasilkan daya generator $0,516 \mathrm{Watt}$, nilai terkecil dalam pengujian dengan kecepatan angin $3,6 \mathrm{~m} / \mathrm{s}$ daya generator sebesar 0,438 Watt.

Nilai daya generator terbesar yang dihasilkan oleh pengujian dengan kecepatan angin $4 \mathrm{~m} / \mathrm{s}$ pada grafik didapatkan daya generator terbesar oleh sudu 7/16 dengan nilai dayanya 0,88 Watt, sedangkan sudu $6 / 16$ menghasilkan daya 0,752 Watt pada pengujian dengan kecepatan $4 \mathrm{~m} / \mathrm{s}$, sedang nilai terkecil dihasilkan sudu 5/16 dengan daya generator yang dihasilkan 0,641 Watt pada kecepatan $4 \mathrm{~m} / \mathrm{s}$.

Dalam pengujian dengan kecepatan angin $4,13 \mathrm{~m} / \mathrm{s}$ daya generator terbesar dihasilkan oleh sudu 7/16 dengan nilai dayanya sebesar 1,071 Watt, sedangkan sudu 6/16 hanya menghasilkan daya sebasar 0,906 Watt yang dilakukan dalam pengujian dengan kecepatan angin $4,13 \mathrm{~m} / \mathrm{s}$, nilai terkecil dalam pengujian dengan kecepatan angin $4,3 \mathrm{~m} / \mathrm{s}$ menghasilkan daya generator 0,703 Watt oleh sudu 5/16.

Hasil pengujian kecepatan angin $4,5 \mathrm{~m} / \mathrm{s}$ nilai yang dihasilkan oleh sudu 7/16 daya generator yang dihasilkan 1,495 Watt dan untuk sudu 6/16 daya yang dihasilkan pada pengujian kecepatan angin $4,5 \mathrm{~m} / \mathrm{s}$ nilai daya generatornya sebesar 1,267 Watt, nila terkecil dalam pengujian dengan kecepatan angin 4,5 $\mathrm{m} / \mathrm{s}$ yaitu pada sudu 5/16 daya yang dihasilkan sebesar 1,003 Watt.

Daya generator terbesar yang dihasilkan oleh pengujian dengan kecepatan angin 4,6 $\mathrm{m} / \mathrm{s}$ pada grafik didapatkan daya generator terbesar oleh sudu 7/16 dengan nilai dayanya 1,506 Watt, sedangkan sudu 6/16 menghasilkan daya 1,29 Watt pada pengujian dengan kecepatan 4,6 $\mathrm{m} / \mathrm{s}$, sedang nilai terkecil dihasilkan sudu 5/16 dengan daya generator yang dihasilkan 1,063 Watt pada kecepatan $4,6 \mathrm{~m} / \mathrm{s}$.

Pengujian kecepatan angin $4,67 \mathrm{~m} / \mathrm{s}$ terhadap hasil daya generator oleh sudu 7/16 menghasilkan daya sebesar 1,522 Watt sedangka sudu 6/16 menghasilkan daya generator 1,336 Watt dan pada pengujian dengan kecepatan angin $4,67 \mathrm{~m} / \mathrm{s}$ sudu $5 / 16$ menghasilkan daya generator sebesar 1,113 Watt.

Berdasarkan hasil pengujian kecepatan angin $5,4 \mathrm{~m} / \mathrm{s}$ nilai yang dihasilkan oleh sudu $7 / 16$ daya generator yang dihasilkan 2,832 Watt dan untuk sudu 6/16 daya yang dihasilkan pada pengujian kecepatan angin $5,4 \mathrm{~m} / \mathrm{s}$ nilai daya generatornya sebesar 2,33 Watt, nila terkecil dalam pengujian dengan kecepatan angin $5,4 \mathrm{~m} / \mathrm{s}$ yaitu pada sudu 5/16 daya yang dihasilkan sebesar 1,965 Watt.

Nilai daya generator terbesar yang dihasilkan oleh pengujian dengan kecepatan angin $5,63 \mathrm{~m} / \mathrm{s}$ pada grafik didapatkan terbesar oleh sudu 7/16 dengan nilai dayanya 2,896 Watt, sedangkan sudu 6/16 menghasilkan daya 2,576 Watt pada pengujian dengan kecepatan $5,63 \mathrm{~m} / \mathrm{s}$, sedang nilai terkecil dihasilkan sudu 5/16 dengan daya generator yang dihasilkan 2,142 Watt pada kecepatan $5,63 \mathrm{~m} / \mathrm{s}$.

Sedangkan dalam pengujian berdasarkan kecepatan angin $6,1 \mathrm{~m} / \mathrm{s}$ nilai yang dihasilkan oleh sudu 7/16 daya generator yang dihasilkan 4,391 Watt dan untuk sudu 6/16 daya yang dihasilkan pada pengujian kecepatan angin $6,1 \mathrm{~m} / \mathrm{s}$ nilai daya generatornya sebesar 3,808 Watt, nila terkecil dalam pengujian dengan kecepatan angin 6,1 $\mathrm{m} / \mathrm{s}$ yaitu pada sudu 5/16 daya yang dihasilkan sebesar 3,014 Watt.

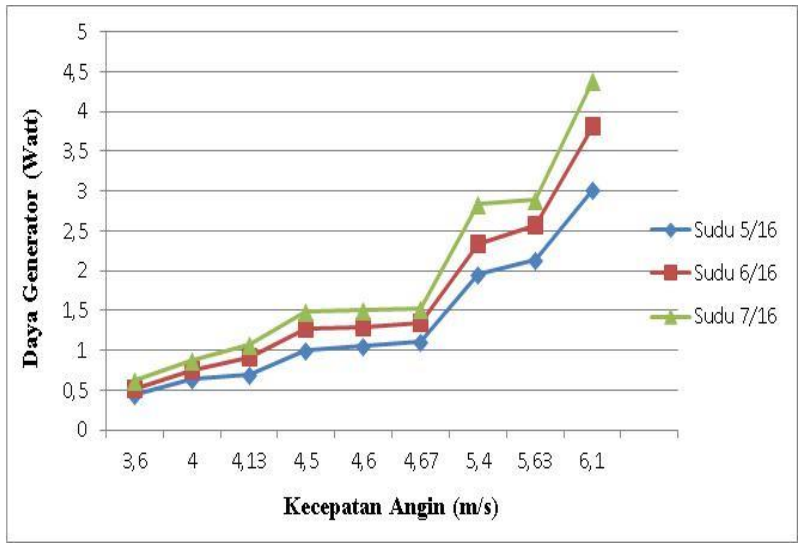

Gambar 5. Grafik Daya generator berdasarkan Variasi Sudu

\section{Efisiensi Sistem yang dihasilkan dengan Variasi Ukuran Blade}

Dari Gambar 6 dapat dilihat bahwa perbandingan efisiensi Sistem terhadap variabel kecepatan angin oleh masing-masing sudu nilai tertinggi dengan kecepatan $3,6 \mathrm{~m} / \mathrm{s}$ pada pengujian dimiliki turbin oleh sudu 7/16 
yaitu sebesar $12,71 \%$, sedangkan sudu $6 / 16$ terhadap variabel kecepatan angin $3,6 \mathrm{~m} / \mathrm{s}$ dalam pengujian efisiensi sistem yang dihasilkan sebesar 10,63\% hal ini lebih kecil dimbanding dengan sudu $7 / 16$ dan $5 / 16$ hasil efisiensi sistemnya $9,02 \%$ nilai tersebut paling kecil di bandinkan sudu 7/16 dan sudu $6 / 16$ pada kecepatan angin 3,6 m/s.

Gambar 5 merupakan grafik perbandingan efisiensi system diketahui nilai efisiensi tertinggi dengan pengujian dalam kecepatan angin $4 \mathrm{~m} / \mathrm{s}$ nilai tertinggi sihasilkan oleh sudu $7 / 16$ dengan efisiensi sistemnya sebesar $13,22 \%$ selain itu sudu $6 / 16$ dengan pengujian menggunakan kecepatan angin yang sama $4 \mathrm{~m} / \mathrm{s}$ menghasilkan efisiensi sistem sebesar 11,29 $\%$ nilai tersebut lebih kecil dibandingkan dengan sudu 7/16 dan pada sudu 5/16 pada pengujian dengan kecepatan angin $4 \mathrm{~m} / \mathrm{s}$ menunjukan nilai yang terkecil pada pengujian yaitu sebesar $9,63 \%$.

Nilai efisiensi sistem ditunjukan oleh grafik dengan kecepatan angin $4,13 \mathrm{~m} / \mathrm{s}$ didapatkan hasil sudu 7/16 sebesar 14,61\%, sedankan pada sudu $6 / 16$ nilai efisiensi sistem yang dihasilkan dengan kecepatan angin 4,13 $\mathrm{m} / \mathrm{s}$ sebesar $12,36 \%$ dan pada sudu 5/16 dengan pengujian menggunakan kecepatan angi $4,13 \mathrm{~m} / \mathrm{s}$ efisiensi sistem yang dihasilkan sebasar $9,59 \%$.

Perbandingan efisiensi sistem diatas didapatkan nilai efisiensi tertinggi dengan pengujian dalam kecepatan angin $4,5 \mathrm{~m} / \mathrm{s}$ nilai tertinggi sihasilkan oleh sudu $7 / 16$ dengan efisiensi sistemnya sebesar 15,77\% selain itu sudu 6/16 dengan pengujian menggunakan kecepatan angin yang sama 4,5 $\mathrm{m} / \mathrm{s}$ menghasilkan efisiensi sistem sebesar $13,41 \%$ nilai tersebut lebih kecil dibandingkan dengan sudu $7 / 16$ dan pada sudu 5/16 pada pengujian dengan kecepatan angin $4,5 \mathrm{~m} / \mathrm{s}$ menunjukan nilai yang terkecil pada pengujian yaitu sebesar 10,58 \% .

Dari grafik dapat dilihat bahwa perbandingan efisiensi Sistem terhadap variabel kecepatan angin oleh masing-masing sudu nilai tertinggi dengan kecepatan $4,6 \mathrm{~m} / \mathrm{s}$ pada pengujian dimiliki turbin oleh sudu 7/16 yaitu sebesar $14,87 \%$, sedangkan sudu $6 / 16$ terhadap variabel kecepatan angin $4,6 \mathrm{~m} / \mathrm{s}$ dalam pengujian efisiensi sistem yang dihasilkan sebesar 12,74 \% hal ini lebih kecil dimbanding dengan sudu 7/16 dan 5/16 hasil efisiensi sistemnya $10,50 \%$ nilai tersebut paling kecil dibandinkan sudu 7/16 dan sudu $6 / 16$ pada kecepatan angin $4,6 \mathrm{~m} / \mathrm{s}$.

Pada gambar diatas menunjukkan bahwa perbandingan efisiensi sistem diatas didapatkan nilai efisiensi tertinggi dengan pengujian dalam kecepatan angin 4,67 m/s nilai tertinggi sihasilkan oleh sudu 7/16 dengan efisiensi sistemnya sebesar 14,36\% selain itu sudu 6/16 dengan pengujian menggunakan kecepatan angin yang sama $4,67 \mathrm{~m} / \mathrm{s}$ menghasilkan efisiensi sistem sebesar $12,61 \%$ nilai tersebut lebih kecil dibandingkan dengan sudu $7 / 16$ dan pada sudu $5 / 16$ pada pengujian dengan kecepatan angin $4,67 \mathrm{~m} / \mathrm{s}$ menunjukan nilai yang terkecil pada pengujian yaitu sebesar 10,50 $\%$.

Grafik diatas menyatakan bahwa nilai efisiensi sistem ditunjukan oleh grafik dengan kecepatan angin $5,4 \mathrm{~m} / \mathrm{s}$ didapatkan hasil sudu $7 / 16$ sebesar $17,29 \%$, sedankan pada sudu 6/16 nilai efisiensi sistem yang dihasilkan dengan kecepatan angin $5,4 \mathrm{~m} / \mathrm{s}$ sebesar $14,22 \%$ dan pada sudu 5/16 dengan pengujian menggunakan kecepatan angi 5,4 $\mathrm{m} / \mathrm{s}$ efisiensi sistem yang dihasilkan sebasar $11,99 \%$.

Gambar grafik perbandingan efisiensi sistem diatas didapat kan nilai efisiensi tertinggi dengan pengujian dalam kecepatan angin $5,63 \mathrm{~m} / \mathrm{s}$ nilai tertinggi sihasilkan oleh sudu 7/16 dengan efisiensi sistemnya sebesar $15,32 \%$ selain itu sudu 6/16 dengan pengujian menggunakan kecepatan angin yang sama $5,63 \mathrm{~m} / \mathrm{s}$ menghasilkan efisiensi sistem sebesar $13,88 \%$ nilai tersebut lebih kecil dibandingkan dengan sudu 7/16 dan pada sudu $5 / 16$ pada pengujian dengan kecepatan angin $5,63 \mathrm{~m} / \mathrm{s}$ menunjukan nilai yang terkecil pada pengujian yaitu sebesar $11,54 \%$.

Sedangkan dalam pengujian berdasarkan kecepatan angin $6,1 \mathrm{~m} / \mathrm{s}$ perbandingan efisiensi sistem diatas didapatkan nilai efisiensi tertinggi dengan pengujian oleh sudu 7/16 dengan efisiensi sistemnya sebesar 18,66 $\%$ selain itu sudu 6/16 dengan pengujian menggunakan kecepatan angin yang sama 6,1 $\mathrm{m} / \mathrm{s}$ menghasilkan efisiensi sistem sebesar $16,13 \%$ nilai tersebut lebih kecil dibandingkan dengan sudu 7/16 dan pada sudu $5 / 16$ pada pengujian dengan kecepatan angin $6,1 \mathrm{~m} / \mathrm{s}$ menunjukan nilai yang terkecil pada pengujian yaitu sebesar $12,76 \%$. 


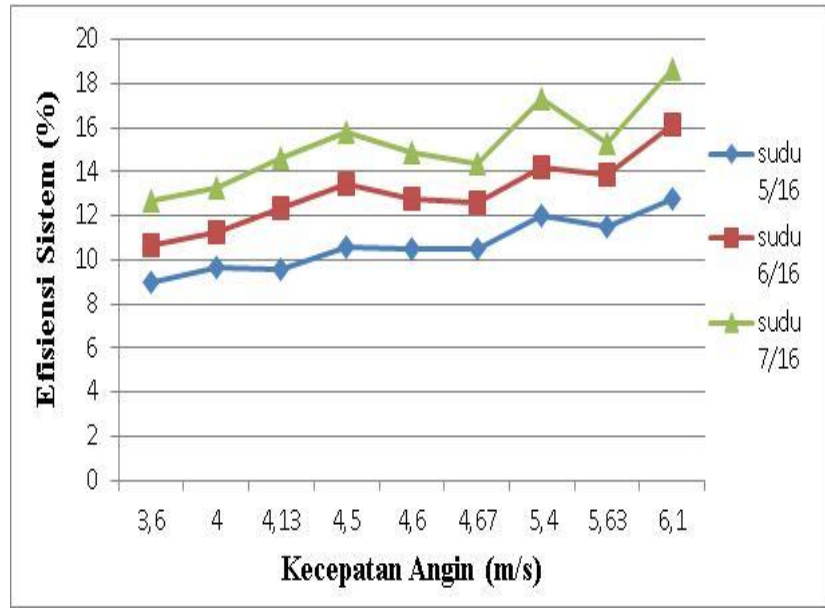

Gambar 6. Grafik efisiensi sistem berdasarkan Variasi Sudu

\section{Kesimpulan}

Menurut hasil dan pembahasan penelitian yang telah dilakukan, maka disimpulkan bahwa :

1. Dari ketiga variasi sudu berdasarkan pengujian beda kecepatan angin desain terbaik yang menghasilkan daya turbin dan daya generator penelitian ini yaitu dimiliki oleh desain sudu 7/16 dengan kecepatan angin yang paling tinggi $6,1 \mathrm{~m} / \mathrm{s}$ menghasilkan daya turbin sebesar 6,125 Watt dan daya generatornya menghasilkan daya 4,391 Watt.

2. Besar efisiensi sistem masingmasing sudu hasil perhitungan dengan pengaruh beda kecepatan angin dengan efisiensi sistem tertinngi didapat oleh sudu 7/16 dengan kecepatan angin $6,1 \mathrm{~m} / \mathrm{s}$ dan nilai efisiensi sistem sebesar 18,66 $\%$, sedangkan nilai efisiensi sistem sudu $6 / 16$ dengan nilai terbesar dihasilkan pada kecepatan angin 6,1 $\mathrm{m} / \mathrm{s}$ dengan nilai efisiensi sistemnya sebesar $16,13 \%$ dan sudu $5 / 16$ efisiensi sistem terbaik dihasilkan dengan pengujian beda kecepatan angin nilai efisiensi sistem sebesar $12,76 \%$ pada kecepatan angin $6,1 \mathrm{~m} / \mathrm{s}$.

\section{Referensi}

[1] Untung Surya Dharma, Masherni, September 2016, Analisa Unjuk Kerja Turbin Angin Vertical Axis Savonius Untuk Pembangkit Listrik Skala Rumah Tangga Di Kota Metro, Prosiding Icositer, ITERA .

[2] Ikhwanul, Ikhsan, Akbar, Hipi, Muhammad, 2011, Analisis Pengaruh Pembebanan Terhadap Kinerja Kincir Angin Tipe Propeller Pada Wind Tunnel Sederhana, Jurnal Teknik Mesin, Fakultas Teknik, Universitas Hasanuddin, Makassar, 2011.

[3] Andri, Kusbiantoro, Rudy, Soenoko, Sutikno, Djoko, Sutikno, 2009. Pengaruh Panjang Lengkungan Sudu Terhadap Unjuk Kerja Turbin Angin Poros Vertikal Savonius. Jurnal Teknik Mesin, Fakultas Teknik, Universitas Brawijaya, Malang.

[4] Muhammad, Fariedl, Faqihuddin, Muhammad, Nizam, Dominicus, Danardono, Dwi, Prija, Tjahjana, 2014, Karakteristik Model Turbin Angin Untwisted Blade Dengan Menggunakan Tipe Airfoil Nrel S833 Pada Kecepatan Angin Rendah, Jurnal Universitas Sebelas Maret, Surakarta.

[5] Teddy, Nurcahyadi, sudarja. 2008. Pengaruh Lokasi Ketebalan Maksimum Airfoil Simetris Terhadap Koefisien Angkat Aerodinamika. Jurusan Teknik Mesin, Fakultas Teknik, Universitas Muhammadiyah Yogyakarta.

[6] Hermann, Jutz, Eduard, Scharkus, 1982. Westermenn Tables, New Delhi, Wiley Eastern Limited.

[7] Astu, Pudjanarsa, Djati, Nursuhud, 2008, Mesin Konversi Energi. Yogyakarta, Andi Offset. 
[8] Joko, Sutrisno, Dani, Setiawan, 2004. Insta Fisika Sekolah Menengah Atas, Jakarta, Erlangga.

[9] Ikhwanul, Ikhsan, Akbar, Hipi, Muhammad, Analisis Pengaruh Pembebanan Terhadap Kinerja Kincir Angin Tipe Propeller Pada Wind Tunnel Sederhana, Jurnal Teknik Mesin, Fakultas Teknik, Universitas Hasanuddin, Makassar, 2011. 